\title{
Exploration and Research on Integrating Olunchun Original Ecological Music into the Teaching of Characteristic Courses in Colleges and Universities
}

\author{
Xu Zuping, Sun Xiaofei \\ Heihe College, Heihe Heilongjiang 164300
}

Keywords: College music; Olunchun original ecological music; Integration strategy

\begin{abstract}
In the current music education in Colleges and universities in China, how to cultivate students'inner core literacy has become the primary teaching goal. Music subjects have certain comprehensiveness and diversity. Teachers should attach importance to the superiority and cultural connotation of minority music in the process of teaching. They should integrate into Oroqen original ecological music in a timely and appropriate way in music curriculum. Through the rational use of various teaching modes, students can feel the broad and profound culture of our country, and draw elements from national culture to create. This paper, taking a small number of Olunchun original ecological music as a starting point, analyzes several points in the music curriculum strategy, hoping to provide some new thinking for the majority of college music teachers.
\end{abstract}

\section{The Significance of Oroqen Original Eco-music integrating into College Music Course}

\subsection{Enriching Music Course Resources in Colleges and Universities}

China has five thousand years of history and culture, and national culture exists as an important part of history and culture. National culture has diversity and uniqueness, which determines that national music has great richness. With the passage of time, national music shows great vitality. Based on this, in the actual teaching process, teachers can integrate Oroqen original ecological music into the music classroom, so that students can access to rich music culture, and can grasp the cultural connotation of national music, so as to realize that students can constantly enrich their music literacy in learning.

\subsection{Enhancing the Viscosity between Different Culltures}

In the process of music teaching in Colleges and universities, through the integration of national cultures, it can enhance the cohesion between different cultures. Students absorb different cultures into their own value system through students. Due to the differences in living habits, ethnic groups and national beliefs, the music culture extended by different nationalities also presents a colorful situation. In music teaching, teachers need to absorb those healthy, positive and upward music cultures, so that multiculturalism can be integrated in the students'knowledge system, and students 
can be presented in the form of music after learning.

\subsection{Conducive to the Personalized Development of Students}

In the current process of music teaching in Colleges and universities, the individualized development of students is the main teaching goal. In the process of teaching, the introduction of Olunchun original ecological music can provide guarantee for students'personalized development. In the process of learning, students can make multiple choices and absorb them. In the process of learning, they can also constantly broaden their horizons and fill their own value system. Students have effective choices in learning all kinds of music, and choose the appropriate music for their own study and creation, to provide guarantee for students'personalized development.

\section{Several Problems in the Integration of Olunchun Original Eco-music into College Music Teaching}

In the current music teaching in Colleges and universities, both textbooks and exercises follow the path of western music culture, neglecting the excellent national culture of our country, and there exists the status quo of "attaching importance to the West" and "despising the nation". Such a situation has led to the university music curriculum to bel canto as the main teaching content. Through the investigation, many teachers and students put most of the class hours in western music learning, and students'works are mainly presented by Bel canto. Such a situation is not conducive to the development of our national Oroqen original ecological music. In the long run, many excellent Oroqen original ecological music are hovering on the edge of disappearance, and it is even more difficult to carry forward. Such a situation should arouse the attention of music educators in Colleges and universities. Through the effective integration of the "national + western" music culture, students should be encouraged to learn from both the rough and the fine in the process of learning.

\section{The Strategy of Oroqen Original Eco-music Integrating into College Music Teaching}

\subsection{Effective Integration of Perceptual Experience and Classroom Teaching}

Music exists as a medium to convey feelings. National music conveys a nation's national culture and characteristics to people. Teachers in the actual teaching process, if they want to successfully carry out the college music classroom based on Olunchun original ecological music, they need to carry out classroom construction from the aspects of emotional transmission, musicality and nationality. Teachers can first construct situations from the background of national music and tell students stories of ethnic groups, so as to promote students'perceptual awareness. Then the students will be shown music works. After the works are played, the core idea of music will be explained, so that the students can think deeply about the situation. At last, the teacher explains the knowledge points in the national music in detail, and constantly consolidates the students'music knowledge system. Through this way of teaching, students can first feel the advantages and diversity of national culture, and integrate the advanced values of national culture into their own value system; secondly, after learning national music, students can choose more styles in their creation, which is conducive to students to create personalized music works.

\subsection{Stimulating Students'Musical Perception Ability}

Our country is a multi-ethnic and multi-cultural country. Different regions have different 
nationalities and different nationalities have different cultures. Such different performances bring comprehensive and comprehensive teaching services to students. Students can broaden their horizons after multi-learning and follow the cultural characteristics to carry out creative work, which is conducive to improving students'internal musical writing comprehensively. Literacy. In the actual teaching process, I collected the original ecological music of Oroqen in our province to carry out teaching work. The original ecological music of Oroqen in our province is closer to students'life. After the explanation, I often lead students to participate in the performance of the original ecological music of Oroqen, and students have gained a lot in the watching process. In addition, in the face of those more profound national cultures, in the preparation stage, the corresponding historical stories, national stories, national cultures and so on will be collected and made into video courseware, and the pictorial explanation will be given to the students in class, which can help the students to produce intuitive knowledge in watching, and the music teaching after the students'cognitive completion can realize the students' comprehensive understanding of national songs. This is the case.

\subsection{Encourage students to use their spare time to carry out independent exercises}

In college vocal music teaching, after-school time is a powerful supplement to classroom teaching. In the actual teaching process, I usually search the network for micro-lessons about ethnic music to make a collection, and then push it to the class group, requiring students to study independently and practice spontaneously after class. In the following classroom teaching, activities can be carried out in the form of activities, such as national cultural awareness sharing, national song class singing competitions, etc., through activities to test the results of students'independent learning in after-school time. This kind of music class is relaxed and pleasant, students feel the cultural connotation of national music in the process of mutual exchange, and also realize the effective sharing of learning experience in the class.

\section{Conclusions}

To sum up, China is a multi-ethnic country, and multi-ethnic cultures together constitute a brilliant Chinese culture. As a carrier of national culture, music plays an important role in music teaching in Colleges and universities. Teachers should attach importance to the importance of national culture in the process of music teaching, make rational use of Olunchun original ecological music to realize the diversity and comprehensiveness of vocal music classroom in Colleges and universities, and promote students to feel the charm of national culture through the joint use of various teaching methods.

\section{Acknowledgement}

Topic: This paper is the annual project of Heilongjiang Philosophy and Social Sciences Research Program. Name: Deep excavation and protective inheritance of Olunchun original ecological music and exploratory research on Teaching of highlighting local characteristics in Colleges and universities, No. 18YSE618.

\section{References}

[1] Ma Shuhao, Liu Hui and Oroqen's practice of integrating original ecological music into music classes in Colleges and universities [J]. Heilongjiang Higher Education Research, 2016 (03): 151-153.

[2] Liu Shuming and Oroqen's inheritance of original ecological music and the reform and innovation of music education in Colleges and universities [J]. Music Creation, 2017 (12): 167-169. 